Problems of World Agriculture volume 19 (XXXIV), number 1, 2019: 5-21 DOI: $10.22630 /$ PRS.2019.19.1.1

\title{
The World Financial Crisis and The Polish Economy
}

\begin{abstract}
The subject of the work is to provide an overview of the global financial crisis in the years 2007-2011; its course, symptoms and effects in the world and in Poland. The work presents the causes and the sources of crisis as well as corrective measures taken by governments and financial institutions. The subject literature and information from different national and international financial institutions and organisations were used as a source of research materials and data for analysis. The financial crisis appeared in Poland with some delay and was less intensive than in other developed countries. Anti-crisis measures taken in Poland complied with the recommendations of the European Union and the International Monetary Fund. The measures taken by the Polish central bank concerned the institutional sphere, the manner in which the financial policy worked and how it was pursued, as well as the real sphere of the economy, including especially enterprises, households and public institutions.
\end{abstract}

Keywords: financial crisis, effects of financial crisis, anti-crisis action, Poland

JEL Classification: G01, H12

\section{Introduction}

Over the last century, two major global economic crises have occurred: the Great Depression that began in 1929 and the Great Recession that broke out in 2007 (IwaniczDrozdowska, 2015, p. 21). The great crisis of the 1930s was regarded more as the largest economic crisis, and the crisis of 2007-2010 was considered as the worst financial crisis. They both led to a collapse in the banking sector and related financial institutions. Irregularities that had been piling up in the banking sector in many countries, especially in the US, can be pointed out as the basis of the most recent financial crisis. The most important irregularities would be excessive bank lending and inadequate analysis of borrower-related risk, including the risk associated with the process of securitization (Kumhof, Zoltan, 2016, p. 50-53). Banks, creating new fiat money, were not able to guarantee the value and stability of the deposited financial means and related investments. Insufficient regulations of the banking and financial systems were not able to prevent crisis phenomena and their consequences could not be avoided both in the first and the second crisis. Explaining the causes and effects as well as the strategies of recovery from the recession of 2007-2010 is currently perceived somewhat differently from the traditional neoclassical theories.

The US economy, which experienced the financial crisis in 2007, as well as economies in other countries, to which the crisis quickly spread, were not prepared for a violent and deep collapse. Both the theory of economics as well as national and international institutions, creating economic and financial policy, were not prepared for the Great

${ }^{1}$ prof. zw. dr hab., Pope John Paul II State School of Higher Education in Biała Podlaska, ul. Sidorska 95/97, 21-500 Biała Podlaska, e-mail: adamowicz.mieczyslaw@gmail.com; https://orcid.org/0000-0002-1164-4966 ${ }^{2}$ MSc, https://orcid.org/0000-0003-0378-3832 
Recession of 2008. The historical experience of the Great Depression of the 1930s also was not used in a satisfactory manner during the implementation of anti-crisis measures.

The financial crisis can be defined as a violation of the stability of the financial market manifesting itself in rapid changes resulting from the lack of liquidity and insolvency of market participants and massive intervention of public authorities aimed at removing adverse effects and preventing further deterioration of the financial system. The contemporary financial system is subject to turbulence and is vulnerable to crises. Financial crisis can take on many forms and the escalation and structure of crisis phenomena can vary. The recent global financial crisis, which began in 2007, is related to the meltdown of the US real estate market (Sławiński, 2008, p. 36-37). The roots of this crisis, however, reach back to earlier periods.

The crisis also affected the Polish economy, including the banking and financial system. Although it turned out to be less severe than in other developed countries, it affected not only the banks and financial institutions, but also enterprises, households, budgets and public finances.

The aim of this study is to present the origin of the financial crisis, the crisis itself and its impact on the global economy, as well as the ongoing corrective measures. The work is based on the reference literature as well as on data and information obtained from national and international financial institutions.

\section{Overview of the financial crisis of 2007-2010}

The financial crisis manifested itself in the US real estate market collapse in the years 2007-2008 (Sławiński, 2008, p. 36-37). However, the causes and symptoms of the crisis can be found earlier. Iwanicz-Drozdowska distinguishes three waves of the financial crisis. The first took place in 2006, when the first American brokerage company, Merit Financial Inc, collapsed (Iwanicz-Drozdowska, 2015, p. 11). In 2007, other brokerage institutions as well as other financial institutions and funds went bankrupt. In Europe, the first wave of the crisis passed relatively mildly and only the collapse of Lehman Brothers, which occurred in the second wave of the crisis, caused significant losses and lack of trust among market participants. The third wave of the crisis appeared in Europe in 2010 when Greece's financial problems escalated. According to IMF economists, in the years 2007-2011, there were eleven cases of systemic banking crises in the EU member states and additionally in several other countries in the world (Costa Navajas, Thegeya, 2013, p. 28).

In the United States, where the crisis developed, two government mortgage lending institutions existed - the Federal National Mortgage Association (Fannie Mae), established in 1938, and the competitive Federal Home Loan Mortgage Corporation (Freddie Mac), founded in 1970. Both are government-sponsored institutions, although in fact they did not have proper government-provided guarantees. The large scale of operations and connection with the state gave the impression that they provided financial stability in the real estate market. This belief resulted from the high credibility of the US economy. Credit claims could easily be converted into securities, which enabled the refinancing of housing credits. The system worked well until 1999, when the creditworthiness criteria were greatly loosened. At that time, the opportunity was created to make credit available to people who did not meet the necessary creditworthiness criteria. As a result, the 'subprime' market was created, with so-called high-risk credit. The securitization process, i.e. transactions, 
resulting in breaking down the credit risk into tranches, caused an increase in the amount of assets that were covered by derivatives. This increased the value of contracts and other derivatives at an alarming level. The activity and effective functioning of markets increased, but at the same time financial institutions became more vulnerable to financial collapse (Nieborak, 2010). Increasing bank lending, transferring risk to purchasers of derivatives and difficulties in assessing the actual nature of risk are the direct reasons that fueled the crisis mechanism. They were not noticed by rating agencies, which failed to communicate proper warning signals before the crisis.

\section{The crisis, its symptoms and immediate corrective measures}

The global financial crisis in the years 2007-2010 consisted of six consecutive phases which included: mortgage credit expansion, increase in raw material prices and declines in the stock market; recession hazard; financial markets collapse; stabilisation attempts; global crisis on the financial market, labour market and raw materials market (Adamowicz, Adamowicz, 2017, p. 87-102). The emergence of crisis phenomena and events as well as corrective measures taken by the state authorities and financial institutions are presented in Table 1.

Table 1. The emergence of crisis phenomena and events as well as corrective and preventive measures taken by governments and financial institutions.

\begin{tabular}{|c|c|c|}
\hline Phenomena and events & $\begin{array}{l}\text { The time of } \\
\text { occurrence }\end{array}$ & Corrective and preventive measures \\
\hline \multicolumn{3}{|c|}{ MORTGAGE CREDIT EXPANSION } \\
\hline $\begin{array}{l}\text { The value of 'subprime' loans reached the level of } \\
\$ 600 \text { billion }\end{array}$ & 2006 & Low interest rates \\
\hline $\begin{array}{l}\text { Growth in real estate prices } \\
\text { Bankruptcy of several loan companies }\end{array}$ & January-June 2007 & $\begin{array}{l}\text { No intervention measures on the financial } \\
\text { markets }\end{array}$ \\
\hline $\begin{array}{l}\text { Collapse of several large companies on the } \\
\text { mortgage market, boom on the American stock } \\
\text { market }\end{array}$ & July-August 2007 & $\begin{array}{l}\text { US government assistance programs for } \\
\text { people paying off loans }\end{array}$ \\
\hline The beginning of the financial crisis in the USA & $\begin{array}{l}\text { September- } \\
\text { October } 2007\end{array}$ & $\begin{array}{l}\text { The Bank of England supports Northern } \\
\text { Rock }\end{array}$ \\
\hline $\begin{array}{l}\text { The first signs of crisis in Europe (England, } \\
\text { Germany) }\end{array}$ & $\begin{array}{c}\text { November- } \\
\text { December } 2007\end{array}$ & $\begin{array}{l}\text { FED loan for the banks amounting to } \$ 41 \\
\text { billion }\end{array}$ \\
\hline \multicolumn{3}{|c|}{ INCREASE IN RAW MATERIAL PRICES AND DECLINES IN THE STOCK MARKETS } \\
\hline $\begin{array}{l}\text { Increase in raw material prices, declines in the } \\
\text { stock markets by } \$ 29.8 \text { billion, decline in retail } \\
\text { sales } \\
\text { Huge losses of the Citigroup banks } \\
\text { Lower employment growth } \\
\text { Societe Generale reports a loss of } € 4.9 \text { billion on } \\
\text { the futures market }\end{array}$ & January 2008 & $\begin{array}{l}\text { Tax exemption package reducing income } \\
\text { of the US budget by } \$ 150 \text { billion } \\
\text { The leaders of Great Britain, France and } \\
\text { Germany, Italy and later also the USA, } \\
\text { Canada and Japan discuss the need to } \\
\text { regulate financial markets }\end{array}$ \\
\hline $\begin{array}{l}\text { Losses reported by the banks in } 7 \text { developed } \\
\text { countries in the world } \\
\text { Losses resulting from the collapse of the real estate } \\
\text { market are estimated at } \$ 100 \text { billion } \\
\text { Redundancies in the banks } \\
\text { The U.S. dollar depreciation } \\
\text { Increase in crude oil prices }\end{array}$ & February 2008 & $\begin{array}{l}\text { Finance ministers at Tokyo Economic } \\
\text { Summit appeal to strengthen supervision } \\
\text { over the banks } \\
\text { Nationalisation of Northern Rock Bank in } \\
\text { the United Kingdom } \\
\text { Lowering the forecast of GDP growth in } \\
\text { the EU for } 2008 \text { from } 2.4 \text { to } 2.0\end{array}$ \\
\hline $\begin{array}{l}\text { Collapse of Bear Stearns, America's fifth-largest } \\
\text { investment bank }\end{array}$ & March 2008 & $\begin{array}{l}\text { The FED decides to inject } \$ 200 \text { billion to } \\
\text { the US banking system and lower the } \\
\text { discount rate } \\
\text { Restoring liquidity also in the UK, Canada } \\
\text { and Switzerland }\end{array}$ \\
\hline
\end{tabular}




\section{M. Adamowicz, T. Adamowicz}

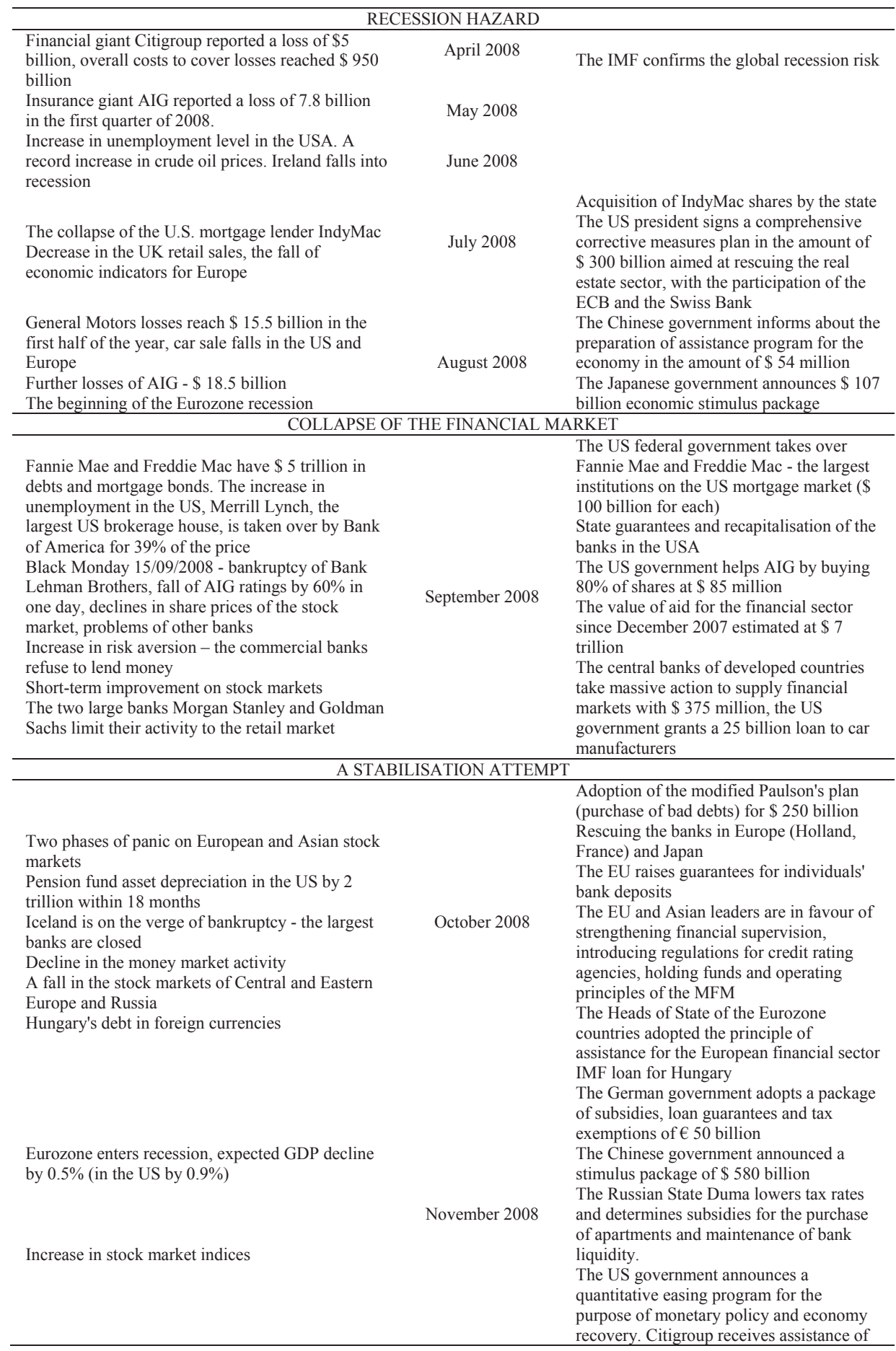




\begin{tabular}{|c|c|c|}
\hline & & $\begin{array}{l}\text { \$ } 320 \text { million } \\
\text { FED spends \$ } 0.5 \text { billion on rescuing } \\
\text { Fannie Mae, Freddie Mac and Federal } \\
\text { Home Loan Banks }\end{array}$ \\
\hline \multicolumn{3}{|c|}{ GLOBAL CRISIS ON THE FINANCIAL MARKET, LABOUR MARKET AND RAW MATERIAL MARKET } \\
\hline Decrease of the profitability of 3-month US & December 2008 & The US government assistance for General \\
\hline Treasury bills. The biggest fall in share prices and & January 2009 & \\
\hline crude oil prices. Decrease in consumption, & & Motors and Chrysler of $\$ 17.4$ billion \\
\hline production and increase in unemployment & & FED lowers interest rates to zero, OPEC \\
\hline The deepening of the crisis on the European & & countries reduce crude oil exploration, \\
\hline continent, Latvia's financial problems & & The European Commission presents an \\
\hline Withdrawal of investors from Central and Eastern & & assistance package $-€ 200$ billion \\
\hline Europe & & International assistance to Latvia \\
\hline \multicolumn{3}{|l|}{ Collapse of the Icelandic Banks } \\
\hline & & $\begin{array}{l}\text { Adoption of the } \$ 825 \text { billion economic } \\
\text { stimulus plan in the USA }\end{array}$ \\
\hline Record low level of interest rates & February 2009 & $\begin{array}{l}\text { The governments of the G8 countries } \\
\text { implement rescue packages of } € 3 \text { trillion }\end{array}$ \\
\hline $\begin{array}{l}\text { Further declines on the stock markets, drop in } \\
\text { sales, and bankruptcy of the banks }\end{array}$ & March 2009 & $\begin{array}{l}\text { Implementation of the financial system } \\
\text { assistance by governments and financial } \\
\text { institutions - including financial assistance } \\
\text { to Romania - } € 20 \text { billion }\end{array}$ \\
\hline & & $\begin{array}{l}\text { The G20 summit takes into account the } \\
\text { need for stricter regulation and supervision }\end{array}$ \\
\hline Some signs of inhibition of crisis trends & April 2009 & of the financial sector, \\
\hline Recovery of the raw material market & Крип 200 & $\begin{array}{l}\text { Establishment of the Financial Stability } \\
\text { Board, the Systemic Risk Board of the }\end{array}$ \\
\hline & & European System of Financial Supervision \\
\hline Russia in Greece - Deficit 13\% of GDP & May 2009 & $\begin{array}{l}\text { The financial assistance program for } \\
\text { Greece } € 140 \text { billion }\end{array}$ \\
\hline
\end{tabular}

Source: R. Holzer: Jak rozwijał się kryzys 2007-2009 - ikonografia Kalendarium Obserwator Finansowy, 18.10.2009; Kryzys gospodarczy w Europie, Kalendarium Kryzysu finansowego, http://forsal.pl.19/3/2015.

The crisis hitting international financial markets brought about major challenges for the governments and the central banks of all countries and international financial institutions, as it caused an economic slowdown which had detrimental effect on the private sector, public sector, enterprises and households, demand and employment as well as on economic trends. New requirements were also set for international and national supervision systems for the banks and financial institutions. Immediate remedial measures undertaken during the crisis were not successful, hence the search for long-term actions to prevent the development of crises. Such measures to counteract the crises continued and were enhanced by economic and financial instruments as well as institutional solutions. Anti-crisis measures were taken in the United States, where the sources of the crisis appeared, as well as in the European Union and other countries that were hit by the crisis. In anti-crisis measures both governments and state organisations as well as the central banks and financial supervisory institutions played an important role. We attempt to present such measures that were taken by selected countries in the world.

One of the applied measures is the so-called quantitative easing (QE). It is a kind of non-standard monetary policy used by the central bank, whose aim is to stimulate the domestic economy. It involves increasing the money supply by means of buying financial assets from the banks. However, this action is threatened with the risk of increase in inflation (Luzowanie..., 2015).

At the time of the financial crisis, the FED reduced interest rates as low as possible, and yet it was unable to control the situation, therefore it decided to apply quantitative easing on a large scale. In March 2009, the US central bank launched the asset purchase program, which was called the QE1 program. As a result, the FED tripled its asset value on 
its balance sheet in a few months. The QE1 program, however, did not bring long-term results, therefore in 2010 it was decided that another program, called QE2, should be launched (Bagus, 2011).

One of the effects of quantitative easing is the increase in prices of shares on stock exchange markets. It results from the fact that additional funds are allocated to investments. Negative effects of quantitative easing may only be visible after a few years. Many economists believe that the continuous use of quantitative easing will not help the US dollar depreciation in order to increase exports, because other countries also decided to implement this policy.

The US Government pays a lot of attention to the activation of the financial market by stimulating demand, increasing financial liquidity and facilitating access to obtain credit, while it is less concerned with reducing the budget deficit or the external debt. It also pays less attention to foreign investors and focuses on supporting domestic financial institutions and enterprises. It is evidenced by financial packages that were provided to the US financial institutions, or the "Buy American" clause, which was included in the American Recovery and Reinvestment Act (Fukuyama, 2011).

As part of Paulson's plan, based on restrictions of \$ 250 billion, launched in September 2008 , the regulations were amended in such a way that the banks could not apply unfair practices against borrowers, who were interested in taking high-risk loans. The collapse of the Lehman Brothers bank forced the FED to buy 79.9\% of AIG's shares in order to prevent its collapse. In addition, the FED lowered the interest rate by 50 basis points to improve the market sentiment. Then a decision of bulk purchase of mortgage credits was taken, later market participants were encouraged to buy toxic assets, at the same time applying for government guarantees for those transactions (Fedor, 2015). The funds that were allocated to combat the crisis were in the first place transferred to major car manufacturers: Chrysler, General Motors and Ford.

The implemented measures did not bring the expected results. Paulson's plan was officially criticised in a letter to the US Congress that was signed by 166 economists, three of whom were Nobel Prize laureates. In the above-mentioned letter economists warned against the harmful effects of this form of assistance to the economy (Kolany, 2015). Timothy Geithner announced his assistance plan in February 2009. It was based on four assumptions: the creation of a financial stability fund through which the banks were to be recapitalised; the purchase of toxic assets supervised by a special investment fund created with the help of private funds; expanding the scale of lending activity and accepting assets as a security for granted loans and providing financial assistance in paying off mortgage loans (Glapiak, 2009).

The above-described activities were to stimulate the recovery of student loans, the credit card market or car loans. There were plans to allocate $\$ 50$ billion for subsidies to repayment of instalments of previously granted mortgage credits. The program was important both for the stability of the banking system, which was provided with a guarantee of systematic repayment of debt installments, and real estate owners, by protecting them against eviction.

The assistance plan for the American banks was not welcomed by financial markets in the world, which contributed to the stock market turmoil. Share prices dropped while stock quotes increased due to doubts that the actions carried out would stimulate the credit market. The US government's interventions partly helped to hinder the economic slowdown, however, due to tax reduction and an increase in public spending on co-financing of the banks, the US significantly increased its budget deficit. As the indebtedness increased, there was a need to increase the issue 
of debt securities, whose profitability should grow so as to encourage investors to buy them. This, in turn, translated into an increase in interest rates on the loans granted, which may lead to a decrease in capital expenditures made by enterprises and household spending. This process may have a negative impact on the US economy in the future.

\section{Causes and sources of the crisis}

There are several theoretical concepts explaining the essence of financial crises and their causes. Friedman associates the financial crisis mainly with panic-based bank runs (Friedman, Schwartz, 1972). Others associate it with a serious deterioration of the major financial indicators (drop in the price of assets: land, real estate, shares), increased insolvency of companies and collapse of financial institutions (Mishkin, 1992). Minsky, Kindleberger et al. believe that a financial crisis occurs when the following phenomena happen: there is a sudden and significant drop in asset prices and many large financial and non-financed institutions collapse, deflation appears, and there is a lot of tension in the currency market (Minsky, 1992). These concepts draw attention to the fact that the financial crisis causes violent disturbances in the financial market. The IMF, referring to the socalled systemic financial crisis, also defines it as serious disturbances in the financial markets resulting in the inability to function effectively, which may have a significant impact on the real economy. In case of the international financial crisis, the disruptions spread beyond the national borders and distort the ability of markets to allocate capital on an international scale (Financial..., 1998). There are several types of crises depending on the sector in which they appear (banking, stock exchange, currency, debt and other) or the area in which they occur (national, regional, local). Crises can also be classified according to the ways and mechanisms of their formation (Borcuch, 2009).

Among many proposals, there are two best known models of crises in the literature: Miskhin's triad model and Minsky's model of investment imbalance and financial instability (Radomska, 2013). Miskhin's model assumes the limited intervention of the state, and is based on three categories: asymmetric information, adverse selection and moral hazard. High interest rates, falling prices on the stock market, increased uncertainty, bank run and unexpected price reductions contribute to the occurrence of these categories. Minsky sees the causes of vulnerability of the modern financial system in such factors as: change in the structure of financing, change in the structure of liabilities, making the repayment of liabilities conditional on the ability to refinance them, dynamic development of modern financial instruments and the ways of regulating the market, increasing the risk-taking willingness.

In a five-stage model, the crisis starts with a disturbance in the form of a significant increase in the price of one of the assets, which allows achieving high profits from a new type of economic activity. Excitement connected with this activity attracts new investors and increases their willingness to take risks. The boom, usually supported by the banks 'loosening' their lending policy, attracts a number of other financial institutions and financial intermediaries. Euphoria among borrowers and lenders leads to a speculative mania, high profits and an overheated economy. The awareness of the unbalanced situation results in asset stripping, decline in prices, bankruptcies, limitation of activity and panic. The financial crisis that started in 2007 in the US has all the features that have been described in the Minsky model. 
The causes of the crisis should be observed in (Falkowski, Teichmann, 2010): phenomena that were the result of the expansive monetary policy of the Federal Reserve of the United States; the lack of efficiency in creating institutional order on a strongly globalized financial market; market failures resulting from the introduction of innovative financial products, which regulatory solutions could not catch up with (Wojtyna (ed.), 2011) due to the fact that in that period a supervisory model based on self-regulation in the financial markets was in force (Konopczak et al., 2010). A turning point in the development of the crisis was the collapse of Lehman Brothers, the third largest investment bank in the USA, which took place in midSeptember 2008. The number of toxic assets in its balance sheet was too high and it incurred huge financial loss because of them. The bank did not obtain the expected government assistance, which was a huge shock to the financial market participants. Many financial institutions lost their financial liquidity due to the outbreak of panic among clients threatened with bankruptcy, who wanted to regain their financial contributions as soon as possible. This raised concerns on the market, which almost led to impediment to the functioning of the credit and interbank markets. Banks realised temporarily the passive role of the government in eliminating the effects of the crisis, and hence, fearing the insolvency of financial partners, ceased to grant credit and loans to financial institutions.

The freezing of the financial market resulted in the emergence of a critical situation in many other banks. Collapse of the financial market quickly moved to the real economy, worsening the situation of households and enterprises. The crisis led to an economic downturn in the US. Aid schemes were taken to support the financial sector, among others, by repurchase of toxic assets, but they were not able to stop the crisis. The crisis spread to other countries and disrupted the functioning of the global economy. In the first place, it affected the banking and insurance sector because they were most involved in toxic assets based on subprime loans. In the aftermath of the crisis, the global economies fell into a recession, which clearly shows a significant drop in the global GDP (the value of which in 2009 decreased by -1.92 points compared to 2008) (Rosati, 2009). The crisis manifested itself in various degrees of intensity and had various consequences in highly developed capitalist economies, emerging economies and developing countries. The spread of the crisis quickly led to the decline in economic activity in the international arena and its consequence was the decline of the global economy in the first quarter of 2009. It was related to two phenomena: a decline in global demand, referred to as a demand shock, and restricted access to short-term funding (Czekaj, 2010).

In an attempt to interpret the causes of the crisis that began in the US in 2007 on the real estate market, the following five sources of this crisis should be taken into consideration:

- Mistakes in economic policy and strategic management.

- The institutional development of financial markets.

- The expansion of new financial market instruments.

- The lack of market transparency, inadequate risk assessments and weak communication.

- The processes and mechanisms of globalisation.

\section{The consequences of the financial crisis for the global economy}

The global crisis on the financial markets impeded the functioning of the global economy. In the first place, it affected the banking and insurance sector because they were most involved 
in toxic assets based on subprime loans. It also hampered the flow of private capital to transformed economies and to most European countries, especially the southern ones. In the aftermath of the crisis, the global economies fell into a recession, which clearly shows a significant drop in the global GDP (the value of which in 2009 decreased by -1.92 points compared to 2008) (Rosati, 2009). The crisis was very intense and it had various effects in highly developed capitalist economies but also in the Commonwealth of Independent States (Nawrot, 2009). The spread of the crisis led to the decline in economic activity in the international arena. There was a significant decrease in international trade (Table 2). The largest collapse of the global trade took place in the fourth quarter of 2007 and in the first quarter of 2009. From September 2008 to February 2009, the exchange of goods decreased by approx. $17 \%$. At the beginning of 2009 , the value of exports decreased by more than $5 \%$ on a quarterly basis in more than $90 \%$ of countries in the world, and for almost $15 \%$ of countries, the decline was over $20 \%$. In 2009 , the value of exports decreased by almost $12 \%$. The decline in trade was particularly severe in the countries where the share of foreign trade was high. The decline in trade was much higher than the decline in world production, which decreased by $3,4 \%$ in developed countries as a consequence of the crisis in 2009. The largest decreases were recorded in Japan, the euro zone countries and the US (Moshirian, 2011). Another negative effect of the crisis in the real sphere was limitation of investment expenditures, both for investments in fixed assets and in inventories.

Table 2. Gross domestic product and world trade in individual regions in 2009-2011 (annual change in \%)

\begin{tabular}{|c|c|c|c|c|c|c|c|c|c|}
\hline \multirow{2}{*}{ Specification } & \multicolumn{3}{|c|}{ Gross Domestic Product } & \multicolumn{3}{|c|}{ Export } & \multicolumn{3}{|c|}{ Import } \\
\hline & 2009 & 2010 & 2011 & 2009 & 2010 & 2011 & 2009 & 2010 & 2011 \\
\hline World & -2.6 & 3.8 & 2.4 & -12.0 & 13.8 & 13.8 & -12.9 & 13.7 & 4.9 \\
\hline North America: & & & & & & & & & \\
\hline USA & -3.6 & 3.2 & 1.9 & -14.8 & 14.9 & 6.2 & -16.6 & 15.7 & 4.7 \\
\hline Central & -3.5 & 3.0 & 1.7 & -14.0 & 15.4 & 7.2 & -16.4 & 14.8 & 3.7 \\
\hline and Southern America & -0.3 & 6.1 & 4.5 & -8.1 & 5.6 & 5.3 & -16.5 & 22.9 & 10.4 \\
\hline Europe & -4.1 & 2.2 & 1.7 & -14.1 & 10.9 & 5.0 & -14.1 & 9.7 & 2.4 \\
\hline EU (27) & -4.3 & 2.1 & 1.5 & 14.5 & 11.5 & 5.2 & -14.1 & 9.5 & 2.0 \\
\hline $\begin{array}{l}\text { The Commonwealth of } \\
\text { Independent States (CIS) }\end{array}$ & -6.9 & 4.7 & 4.6 & -4.8 & 6.0 & 1.8 & -28.0 & 18.6 & 16.7 \\
\hline Africa & 2.2 & 4.6 & 2.3 & -3.7 & 3.0 & -8.3 & -5.1 & 7.3 & 5.0 \\
\hline The Middle East & 1.0 & 4.5 & 4.9 & -4.6 & -4.8 & 5.4 & -7.7 & 7.5 & 5.3 \\
\hline Asia & -0.1 & 6.4 & 3.5 & -11.4 & -11.4 & 6.6 & -7.7 & 18.2 & 6.4 \\
\hline China & 9.2 & 10.4 & 9.2 & -10.5 & -10.5 & 9.3 & 2.9 & 22.1 & 9.7 \\
\hline Japan & -6.3 & 4.0 & -0.5 & -24.9 & -24.9 & -0.5 & -12.2 & 10.1 & 1.9 \\
\hline India & 6.8 & 10.1 & 7.8 & -6.0 & -6.0 & 16.1 & 3.6 & 22.7 & 6.6 \\
\hline $\begin{array}{l}\text { Newly industrialising } \\
\text { countries }\end{array}$ & -0.6 & 8.0 & 4.2 & -5.7 & -5.7 & 6.0 & -11.4 & 17.9 & 2.0 \\
\hline $\begin{array}{l}\text { Highly developed } \\
\text { economies }\end{array}$ & -4.1 & 2.9 & 1.5 & -15.1 & -15.1 & 4.7 & -14.4 & 10.9 & 2.8 \\
\hline $\begin{array}{l}\text { Emerging economies and } \\
\text { CIS }\end{array}$ & 2.2 & 7.2 & 5.7 & -7.4 & -7.4 & 5.4 & -10.5 & 18.1 & 7.9 \\
\hline
\end{tabular}

Source: www.wto.org/english/news-e/pres12_e/pr658_w.htm\#table1 (15.03.2012 - date of accessing online) 
The crisis most severely affected the highly developed countries because they had greater access to instruments whose markets collapsed during the crisis. It manifested itself in a huge decrease in international trade in goods or production since the fourth quarter of 2008 (Global..., 2010). Financial institutions in emerging economies, which include, among others, Poland, were not so much affected by the direct losses from investments in derivatives, due to their low popularity and poor availability. The economies of highly developed countries and emerging countries experienced the consequences of crisis due to:

- the decline in demand, especially on financial markets in highly developed countries, which led to the collapse of global exports;

- the turmoil in the financial and currency markets, which caused rapid changes in exchange rates, especially in emerging countries, and the withdrawal of capital by financial institutions operating on the international market, which wanted to compensate for the loss incurred (Czekaj, 2010).

There was a significant decline in international trade flows. From September 2008 to February 2009, the exchange of goods decreased by approx. 17\%. At the beginning of 2009 , the value of exports decreased by more than $5 \%$ on a quarterly basis in more than $90 \%$ of countries in the world, and for almost $15 \%$ of countries, the decline was over $20 \%$. In 2009 , the value of exports decreased by almost $11 \%$. The decline in trade was much higher than the decline in world production, which decreased by $3,4 \%$ in developed countries as a consequence of the crisis in 2009. As mentioned earlier, the largest decreases were recorded in Japan, the euro zone countries and the US.

Another negative effect of the crisis in the real sphere was the limitation of investment expenditures, both for investments in fixed assets and in inventories. The main reasons for the slowdown in investment among enterprises were: the collapse in demand, the precarious situation of the global economy in the future; the low production capacity utilisation; the decrease in profit margins; tightening of conditions for financing operations. For example, in Europe, investments in fixed assets decreased by almost $14 \%$ as compared to 2008 .

Analysis of the investment rate in the Eurozone countries shows that the downward trend, which had begun in the fourth quarter of 2008, ended in the second half of 2010. This resulted from the restructuring of corporate balance sheets and the slow increase in the production capacity utilisation, as well as from the fact that the process of restoring the willingness of entrepreneurs to invest is difficult and long-lasting.

In addition to the above-described consequences of the outbreak of the financial crisis, a number of others can be mentioned, including (Adamczyk, 2015):

- Declaration of bankruptcy or acquisitions of many financial institutions and nationalisation of institutions that were threatened with bankruptcy;

- Collapse of stock markets in the USA, UK, Eurozone countries and Asian countries;

- Losses incurred by investment and pension funds, which invested mainly in the stock markets.

- Increase in the government expenditures for co-financing of the banks and other financial institutions, stabilisation of financial markets and other interventions.

- Increase in budget deficit and public debt, especially in Japan, the Eurozone and the USA (Nawrot, 2009).

The recent financial crisis has certainly shown that mistakes made in the financial sector threaten the proper functioning of the real economy, and the consequences of wrong 
decisions taken by financiers affect not only financial institutions, but also have significant influence on the situation of households, enterprises and local government institutions.

The positive aspect of the crisis was the introduction of changes that would never have be implemented under "normal" conditions.

\section{The global financial crisis and the Polish economy}

Poland, participating in global processes, was also exposed to the global financial crisis, although the Polish economy initially managed to avoid the crisis. Among the main risks that have been mentioned were the following: the risky dependence of the Polish zloty on speculative short-term investments; the high public debt; and the large share of imports in production.

Then, however, other factors which caused the emergence of the financial crisis in Poland appeared, namely: the limited lending by the banks and the attack of speculators on the Polish currency resulting in the significant reduction of its value. Nevertheless, compared to other European countries, the situation prevailing in Poland was evaluated positively. The most important measure of the general state of the country's economy, which is GDP, during the outbreak of the financial crisis was at a favourable level (Table 3).

Table 3. Changes in GDP and domestic demand in Poland in the years 2007-2013 in \%

\begin{tabular}{l|ccccccc}
\hline \multicolumn{1}{c|}{ Specification } & 2007 & 2008 & 2009 & 2010 & 2011 & 2012 & 2013 \\
\hline GDP & 6.7 & 4.9 & 1.8 & 3.9 & 4.0 & 2.0 & 1.2 \\
Domestic demand & 8.4 & 5.6 & -1.1 & 4.6 & 3.6 & 2.3 & 1.2 \\
\hline
\end{tabular}

Source: CSO Quarterly accounts of GDP in the years 2007-2013. Available online: stat.gov.pl, [online.10.04.2015]

The high value of GDP in 2007-2008 was influenced i.e. by domestic demand, which had strengthened due to the development of investments, which resulted from the inflow of capital to Poland, which took the form of foreign direct investment and increased use of EU funds. The increase in consumption was also an important factor, which occurred as a result of the improvement of the situation on the labour market and the decrease in the unemployment rate, the increase in the amount of remunerations, the increase in the household indebtedness, the transfer of EU funds to farmers and the transfer of the income from working abroad.

In the year 2009 there was a severe global economic downturn. Among the European countries, only Poland managed to maintain positive GDP growth. Exports, public investments and private consumption had contributed to this situation. On the other hand, the decline in domestic demand in 2009 was a result of the deteriorating situation on the labour market (Miszkin, 2002). In 2010, there was a small but noticeable improvement in the global macroeconomic situation. Among the 27 EU Member States - 22 countries reported a positive GDP growth rate. Poland was in the forefront, only slightly behind Slovakia and Sweden. The improvement of the economic situation prevailing in Poland in 2010 and its continuation in the subsequent years was the result of a recovery of its trading partners. External demand had stimulated industrial production and had improved the situation on the labour market. 
However, the global financial crisis had a strong impact on public finances in Poland, both in terms of the central budget and budgets of local governments (Satoła, 2012). The effects of the financial crisis at the macroeconomic level contributed to the increase in the budget deficit and the accumulation of public debt and the rising costs of debt servicing resulting from it as well as the loss of trust in the financial markets. State budget revenues amounting to PLN 274.4 billion in 2009 decreased to PLN 250.3 billion in 2010, while expenditures increased from PLN 277.9 billion to PLN 298.2 billion in 2009, and slightly decreased to PLN 294.9 billion in 2010. The budget deficit increased sharply from around PLN 24 billion in 2008-2009 to PLN 44.6 billion in 2010 and reached the level of PLN 40.2 billion in 2011. A significant increase in budget imbalance forced the need to take remedial measures in the area of public finances.

Polish enterprises were more strongly affected by the long-term effects of the financial crisis despite the fact that its short-term effects affected the country less than other EU countries. One of the negative effects of the crisis, that influenced the business, was reduction of the possibility of financing their operational and investment activities. Due to the decrease in trust in the financial market and the deterioration of the financial condition of the banks, the access to credit decreased and the costs of obtaining loans increased. This was particularly the case for small and medium-sized companies. In turn, large enterprises had problems with obtaining a syndicated loan granted in order to finance large projects by a group of banks. Difficulties, which affected enterprises, quickly moved to the labour market, which resulted in the reduction of employment and growing concerns about job loss. As a result of such events, the consumer demand decreased: in March 2009, there was a decline in retail sales by approx. $1.8 \%$ on an annual basis. As a result of difficulties in access to financing payment gridlocks, situations of companies deteriorated and many of them were declared bankrupt. In the first quarter of 2009, 105 bankruptcies were recorded, which meant an increase of $11 \%$ compared to the previous year, when at the same time 95 bankruptcies were recorded (Ministry..., 2015).

The financial crisis affected also the Warsaw Stock Exchange. The WSE suffered heavily from the effects of the crisis in Warsaw in 2008, which is confirmed by the rates of return of the most important stock exchange indices (Table 4).

Table 4. Formation of the rate of return of selected indices of the Warsaw Stock Exchange in 2007-2010, at the time when the stock exchange experienced the consequences of the crisis

\begin{tabular}{l|cccc}
\hline \multicolumn{1}{c|}{ Indices } & 2007 & 2008 & 2009 & 2010 \\
\hline WIG20 (\%) & 5.19 & -48.21 & 33.47 & 14.88 \\
WIG-PL (\%) & 9.23 & -50.62 & 44.93 & 18.70 \\
mWIG40 (\%) & 7.90 & -62.48 & 55.24 & 19.57 \\
sWIG80 (\%) & 25.17 & -56.95 & 61.85 & 10.18 \\
\hline
\end{tabular}

Sources. Basic statistics of the WSE. Available online at: http://www.gpw.pl/analizy_i_statystyki_pelna_wersja [online: 30.04 .2015 ].

Deterioration of the situation on the WSE was already apparent in 2007, when all indices recorded low rates of return. A Polish capital market crash occurred when the global recession reached its climax in 2008. Data from 2009 demonstrate that in the period of an economic slowdown in Poland, small companies, whose rate of return was $61,85 \%$, and medium companies, whose rate of return on investment was $55,24 \%$, fared best. However, 
the improvement was not permanent. In 2010, the Warsaw Stock Exchange indices continued to show positive rates of return, but compared to the previous year, there was a decreasing tendency (Gruszczyńska-Brożbar, 2009).

The effects of the financial crisis in the household sector were clearly recorded at the turn of 2008-2009. Households first had to face tightening of bank lending policy. Over $85 \%$ of the banks did so, of which approx. $20 \%$ significantly tightened their requirements (Sytuacja..., 2009). Decisions taken by the banks were unexpected and were mainly driven by changes that occurred on the interbank market. A survey conducted by the NBP showed that each of the conditions for granting a housing credit was tightened, i.e.: almost $75 \%$ of the banks increased their credit margin; around $90 \%$ of the banks increased the amount of the required own contribution; over $40 \%$ of the banks increased non-interest credit costs; almost $20 \%$ of the banks reduced the maximum credit term; about $75 \%$ of the banks tightened other requirements regarding the granting of housing credits that were not included in the survey. Tightened requirements concerned, among others, determining the borrower's creditworthiness, gathering documents confirming the borrower's income as well as the real property valuation principles.

On the basis of the survey conducted by the NBP it has been ascertained that the vast majority of banks also tightened their requirements for granting a Swiss franc-denominated housing credit. The most important reasons for tightening the lending policy regarding the granting of housing credits included: the risk related to the economic situation in Poland; forecasts that concerned the situation on the housing market; unfavourable assessment of the current and prospective capital situation of particular banks.

The first negative effect of the tightening of the lending policy by the banks was the decline in demand for housing loans. This was the case despite the fact that the prices of real property were decreasing. The second reason why people resigned from taking loans was the uncertain situation on the labour market. It should be emphasised that the crisis contributed to the reduction of inflationary pressure. This was the basis for enabling the Monetary Policy Council to reduce interest rates in the country. Reference rates increased from April 2007 to June 2008 and then they began to decrease. As a result of six consecutive reductions, the reference rate decreased from $6 \%$ in November 2008 to $3.5 \%$ in June 2009 , which was a reduction by almost $42 \%$ within eight months.

The survey conducted by the NBP showed that the tightening of bank lending policy concerned also consumer loans. Nevertheless, the change in the requirements for granting such loans was in line with expectations. Tightening of the policy of granting consumer loans consisted of: raising margins by approx. $40 \%$ of the banks; increasing non-interest credit costs by approx. $13 \%$ of the banks; increasing the requirements for credit collateral by $22 \%$ of the banks; reducing the maximum credit amounts by approx. $15 \%$ of the banks. The most important reasons for tightening of lending policy in the field of consumer credits included: the risk related to the uncertain economic situation of the country; the deterioration of the capital situation of the banks surveyed; the deterioration of the quality of the credit portfolio.

As a result of more difficult access to consumer loans, there was an increase in household debt and the costs of servicing it. In the years 2007-2008, during the period of economic growth, when the unemployment rate decreased and real wages grew, the rising pace of household debt growth was noticeable. Due to the global financial crisis, there was a depreciation in the value of the Polish zloty, as compared to other world currencies. The sharp depreciation of the Polish zloty especially as compared to the Swiss franc, resulted from the fact that the household debt, as a result of taking housing loans in a foreign 
currency, increased from the third quarter of 2008 to the end of the fourth quarter of 2008 from almost PLN 97 billion to over 134, PLN 9 billion which is over 48\%.

The crisis contributed to substantial changes on the labour market. When the crisis reached Poland in 2008, the situation of the employed persons was good. According to the Central Statistical Office (GUS), the increase reached 6.0\% compared to 2007. The unemployment rate decreased by $2.87 \%$ as compared to 2007 . Real wages also increased. This positive trend did not last long. As a result of the falling demand for products and services, employers began to cut costs, including employment-related costs. The rate of unemployment registered from 2008 to the end of 2009 , according to the data provided by the Central Statistical Office, increased by $1.15 \%$. While in 2008 there was an upward trend in the number of employed persons, from 2009 their continuous decline was recorded, which resulted in an increase in the number of unemployed people in the country. From 2008 to 2013, the number of unemployed persons increased to $3.71 \%$. The liquidation and bankruptcy of enterprises during the crisis had a negative impact on this situation. Costcutting led to the decrease in monthly real wages, so persons who were employed on a fulltime basis had to accept the reduction of their income. Changes in the labour market raised concerns about job loss among employees, which could have contributed to the reduction of propensity to consume and incur long-term liabilities.

The previously described phenomena concerning the limitation of the state budget revenues, increase in a budget deficit and growing public debt had an adverse effect also on the finances of local authorities and all public sector entities. This was reflected by limitation of the revenues of public entities, the necessity to raise expenditures in order to mitigate the negative impact of the crisis and seeking ways to counteract downward trends, as well as opposing economic recession and stagnation in the regional and local systems.

The description of the financial crisis and its effects in Poland presented herein clearly indicates the delay of the phase of a business cycle. The year 2007 in Poland, when the crisis appeared in the US and other countries, should be considered a year of prosperity and economic growth. Unfortunately, crisis-related global phenomena quickly hit the Polish economy. The analysis of the consequences of the crisis for Polish trade, investments, production or employment indicates, however, that the real sphere of the economy in Poland relatively quickly managed to escape from the collapse. However, the escape from the crisis in the financial sector was delayed. There was still a threat resulting from the instability in financial markets and impairment of financial institutions. It turned out that a stable international financial system is therefore the prerequisite for a faster development of the national economy.

It should be stated that the appearance of the financial crisis in 2007 caused a quick reaction of the countries in the form of adoption of recovery plans and introducing specific measures in various fields, both in the financial sector and real economies. In Poland, the anti-crisis program was related to the activities of the European Union. The European Commission on November 28, 2008, presented a rescue plan for the economy. The corrective measures were based on two fundamental concepts. The first included: mobilisation of short-term funding to increase the demand; maintaining existing jobs, through training and retraining of employees; restoring people's trust in financial institutions (EC European..., 2008). The second concept was based on "smart investments". Their aim was to yield higher growth and sustainable prosperity in the longer-term. EUR 200 billion was allocated for the implementation of the package, which accounted for $1.5 \%$ of GDP of EU. The package assumed the fulfilment of three strategic goals with the use of 
the indicated funds, and they included: quick stimulation of the demand side and restoring confidence to the market; the reduction of social costs resulting from the financial crisis, accelerating the transformation of the EU economy into a low-carbon economy. Member States were authorised to take anti-crisis measures. The Commission suggested that the Member States take specific solutions aimed at the promotion of entrepreneurship or conducting relevant research. The anti-crisis measures of the European Union and national governments were supported by the European Central Bank, the European System of Central Banks and other international financial institutions.

\section{Conclusions}

1. The recent financial crisis, called the Great Recession, was caused by various kinds of irregularities that appeared in the financial sector in many countries around the world, especially in the banking and the real estate sector in the United States. It had a number of reasons, among which the most important were excessive bank lending with incorrect credit risk assessment, including the risk associated with the securitization process.

2. Despite the remedial and corrective measures undertaken by financial institutions and the US government, the crisis quickly spread to other countries in the world, especially to the developed countries, and it also included emerging economies, like Poland. The phenomena of the financial crisis appeared in the Polish economy a little bit later and had milder forms.

3. The global financial crisis of 2007-2011 affected enterprises, households, as well as state and local government institutions. It manifested itself as the slowdown in economic growth, especially in 2008 when there was a significant fall in stock market indices and enterprises were experiencing high losses, and in 2009, when the lowest rates of GDP growth and very weak domestic demand were recorded. In the macroeconomic system we can also observe the second wave of the crisis which occurred in the years 2012-2013.

4. Anti-crisis and corrective measures in Poland were taken by the government, its institutions and the National Bank of Poland. They also resulted from the adaptation and adjustment activities of business entities and local self-governments. The abovementioned activities in Poland were conducted in cooperation with both the European Union institutions and international financial institutions. Anti-crisis and preventive measures concerned both the institutional sphere, the manner in which the financial system worked and how financial policy was pursued, as well as the adjustments made in the real spheres of the economy.

\section{Bibliography}

Adamczyk, M. (2015). Współczesny kryzys finansowy - przyczyny i konsekwencje dla gospodarki światowej (Contemporary financial crisis - causes and consequences for the world economy). Prace $i$ Materiaty Instytutu Handlu Zagranicznego Uniwersytetu Gdańskiego, 31, 13-29.

Adamowicz, M., Adamowicz, T. (2017). Łagodzenie skutków i działania naprawcze jako reakcja na światowy kryzys finansowy w latach 2007-2010 (Alleviating the crisis effects and retrieving anticrisis activities as reaction for global financial crisis 2007-2010). Przedsiębiorstwo \& Finanse, 2(17), 87-102. 
Bagus, P. (2011). Czy dojdzie do trzeciego, czwartego i piątego ilościowego luzowania? (Will there be a third, fourth and fifth quantitative loosening?). Available 20.05.2015 from: http://mises.pl/wp-content/uploads/2011/01/ Bagus-czydojdzie-do-trzeciego-czwartego-i-piatego-ilosciowego-poluzowania.pdf.

Borcuch, A. (2009). Globalny system pieniężny (The global monetary system). CeDeWu Press, Warsaw.

Costa Navajas, M., Thegeya, A. (2013). Financial soundness Indicators and Banking Crisis, IMF Working Papers, No. $13 / 263$ p. 28 .

Czekaj, J. (2010). Wpływ światowego kryzysu gospodarczego na polską gospodarkę (The impact of the global economic crisis on the Polish economy). In: G. Kołodko (ed.) Globalizacja, kryzys i co dalej? Poltext Sp. z o.o., Warsaw, 189-209.

EC European Economic Recovery Plan 2008. Available 20.07.2015 from: ec.europaeconomy.eu.

Falkowski, K., Teichmann, E. (ed.) (2010). Państwa bałtyckie i Europy Wschodniej. Reakcja na światowy kryzys gospodarczy i regionalny kryzys gazowy (The Baltic States and Eastern Europe. Reaction to the global economic crisis and regional gas crisis). SGH, Warsaw, 50-55.

Fedor, P. (2015). Działania FED w kryzysie (FED actions in a crisis). Available 30.06.2015 from: http://www.hossaprocapital.ue.wroc.pl/index.php?option=com_content\&view=article\&id=27:dziaania-fedw-kryzysie $\&$ catid $=4$ :referaty $\&$ Itemid $=9$.

Financial Crises: Characteristics and Indicators of Vulnerability (1998). World Economic Outlook, Chapter IV, International Monetary Fund.

Friedman, M., Schwartz, A. (1972). A monetary history of the United States: 1867-1960. Princeton University Press.

Fukuyama, F. (2011). Nie stać nas na kapitalizm (We can not afford capitalism). „Foreign Affairs”, transl. „Forum”, April 26, 2011. Available 15.06.2015 from: http://www.polityka.pl/tygodnikpolityka/swiat/1515186,nie-stac-nas-nakapitalizm.read.

Glapiak, E. (2009). Pesymizm rodzi recesję (Pessimism creates a recession). Rzeczpospolita, 74, Warsaw.

Global Financial Stability Report, 2010, International Monetary Fund, Washington DC April. Available from: https://www.imf.org/external/pubs/ft/gfsr/.

Gruszczyńska-Brożbar, E. (2009). Funkcjonowanie GPW w Warszawie w świetle światowego kryzysu finansowego (The functioning of the Warsaw Stock Exchange in the light of the global financial crisis). ZN US Ekonomiczne Problemy Ustug, 40, 129-136.

GUS, Stopa bezrobocia w latach 1990-2015 (Unemployment rate 1990-2015). Available 15.05.2015 from: http://stat.gov.pl.

GUS, Rachunki kwartalne PKB w latach 2007-2013 (Quarterly national accounts 2007-2013). Available 10.04.2015 from: stat.gov.pl.

GUS, Raport o stanie sektora małych i średnich przedsiębiorstw (Report on the state of the sector of small and medium enterprises). Available 21.08.2015 from: www.pi.gov.pl.

Iwanicz-Drozdowska, M. (2015). Restrukturyzacja banków Unii Europejskiej w czasie globalnego kryzysu finansowego (Restructuring of European Union banks during the global financial crisis). Oficyna Wydawnicza SGH, Warsaw.

Kolany, K. (2015). Ekonomiści krytykują Plan Paulsona (Economists criticize Paulson's Plan). Available 30.06.2015 from: http://www.bankier.pl/wiadomosc/Ekonomisci-krytykuja-8222-Plan-Paulsona-82211836919.html.

Konopczak, M., Sieradzki, R., Wiernicki, M. (2010). Kryzys na światowych rynkach finansowych - wpływ na rynek finansowy w Polsce oraz implikacje dla sektora realnego (Global financial markets crisis - impact on the Polish financial market and implications for the real sector of the economy). Bank i Kredyt, 6, 45-70.

Kumhof, M., Zoltan, J. (2016). The truth about Banks FD Finance and Development, A Quarterly Publication of the International Monetary Fund, March 2016, 53(1), 50-53

Luzowanie ilościowe (Quantitative loosening). Available 17/05/2015 from: http://finansopedia.forsal.pl/wiki/ Luzowanie ilo\% $5 \% 9$ Bciowe.

Ministry of Finance. Informacja kwartalna o sytuacji makroekonomicznej i stanie finansów publicznych (Quarterly information on the macroeconomic situation and the condition of public finances). Available 24.04.2015 from: www.wneiz.pl/nauka.

Minsky, H. (2000). The Financial Instability Hypothesis, Levy Economics Institute Working Paper 1992, No. 74; Ch. Kindleberger, Manias, Panics and Crashes: A History of Financial Crises, 4th Edition, John Wiley and Sons Inc.

Mishkin, F. (1992). Anatomy of Financial Crisis. Journal of Evolutionary Economics, 2(2), 115-130.

Miszkin, F.S. (2002). Ekonomika pieniądza, bankowości i rynków finansowych (The economics of money, banking and financial markets). PWN, Warsaw. 
Moshirian, F. (2011). The global financial crisis and the evolution of markets, institutions and regulation. Journal of Banking and Finance, 35(3), 502-511.

Nawrot, W. (2009). Globalny kryzys finansowy XXI wieku. Przyczyny, przebieg, skutki, prognozy (Global financial crisis of the 21 st century. Causes, course, effects, forecasts). Wyd. CeDeWu, Warsaw.

Nieborak, T. (2010). Globalny kryzys finansowy, istota, przyczyny, konsekwencje (Global financial crisis - the essence, reasons and consequences). Ruch Prawniczy, Ekonomiczny i Socjologiczny, 72(4), 95-106.

Podstawowe Statystyki GPW (Basic Statistics of the Warsaw Stock Exchange). Available 30.04.2015 from: http://www.gov.pl.

Radomska, E. (2013). Globalny kryzys finansowy - przyczyny, przebieg, skutki (Global financial crisis - causes, trajectory, consequences). Zarzadzanie Zmianami 2-3, 1-21.

Rosati, D. (2009). Przyczyny i mechanizmy kryzysu finansowego w USA w latach 2007-2009 (Causes and mechanism of the financial crisis in USA 2007-2009). In: G. Kołodko (ed.) Globalizacja, kryzys i co dalej? Poltext Sp. z o.o., Warsaw.

Sławiński, A. (2008). Przyczyny globalnego kryzysu bankowego (Causes of the global banking crisis). Materiały konferencyjne pt. Nauki społeczne wobec kryzysu na rynkach finansowych, Kolegium EkonomicznoSpołeczne Szkoły Głównej Handlowej, Warsaw.

Sotała, Ł. (2012). Kryzys finansów publicznych z perspektywy społeczności lokalnej. Roczniki Naukowe SERiA, 14(4), 104-109.

Sytuacja na rynku kredytowym. Wyniki ankiety dla przewodniczących komitetów kredytowych (The situation on the credit market. Survey results for chairpersons of credit committees). Departament Systemu Finansowego NBP, Warsaw, 2009. Available 15.05.2015 from: http://www.nbp.pl.

Wojtyna, A. (ed.). (2011). Kryzys finansowy i jego skutki dla krajów na średnim poziomie rozwoju (The financial crisis and its consequences for countries on the medium level of development). PWE, Warsaw.

\section{For citation:}

Adamowicz M., Adamowicz T. (2019). The World Financial Crisis and The Polish Economy. Problems of World Agriculture, 19(1), 5-21; DOI: 10.22630/PRS.2019.19.1.1 